\title{
わが国における牧草地の雑草群落とその動態
}

\author{
第 2 報 北海道（札幌市・帯広市周辺）における雑草群落の動態
}

東北大学農学部農場 酒井 博 - 佐藤徳雄

横浜国立大学環境科学研究センター 奥 田重 俊

農林水産省草地試験場川 鍋 祐 夫

前報 ${ }^{6)}$ で，筆者らは北海道の牧草地調査について，牧 草および雑草の種の結び付きに基礎をおいた植物社会学 的な面から解析を行い, 牧草地の雑草群落を III型 7 群に 区分し，各種群落の特徴を明らかにした。

本報では, さらに各種群落の動態とその要因について 考察を行い，また雑草群落と生活型との関係について明 らかにして, 雑草による牧草地の診断および雑草防除の 基礎資料 ${ }^{1,3)}$ としたい。

\section{1. 調查地および調查方法}

本調査は，すべて前報で報告した調査と同時に行った ものであり, 調査地域, 調查地点, 調查時期および調査 方法など全く同一である。

\section{2. 調査結果および考察}

\section{（1）各程雑草群落の程組成}

前報で，その特徴を明らかにした北海道（札幌市・帯 広市周辺）における牧草地の雑草群落 III 型 7 群につい て, その種組成の比較を第 1 表の総合常在度表 ${ }^{2)}$ に示し た。

これは, 前報における各種群落表を素材にしてまとめ たもので, 最上段の群落区分番号のうち，1〜 7 はシ口 ザーイヌタデ型群落, 8 〜 は典型群落, 10〜11 はへラ
オオバコ型群落を示している。表中の草種は，上段が播 種牧草, 中段が区分種, 下段が随伴種であり, 区分種の らち実線で囲んだグループが上位区分種, 点線で囲んだ グループが下位区分種である。従って上位区分種のう ち, イヌタデ・ハコベ・シロザ・ナズナの種群を含む群 落がシロザーイヌタデ型で, ヘラオオバュ・ヒメスイ バ・メマツヨイグサ・スギナ・ゲンノショウコの種群を 含む群落がへラオオバコ型であり，特別の種群を含まな い群落が典型である。

これら 3 型の群落は, さらに点線で囲んだ下位区分種 によって, 1 : ホソアオゲイトウ群, 2 〜 : スズメノ カタビラ群 ( 2 =八イミチヤナギ小群, 3 =典型小群), $4 \sim 7$ : 典型群 ( 4 =ナギナタコウジュ小群, $5=$ リー ドカナリーグラス小群， 6 =ケンタッキーブルーグラス 小群, 7 =レッドトップ小群), 8 : 典型群, 9 : オオ チドメ群, 10 : 典型群, 11 : ブタナ群の 7 群（小群を加 えると 11 群) に区分される。表に示したように, 播種牧 草のらちオーチャードグラス・ラジノクローバはすべて の群落に出現しており，雑草では随伴種の項でセイヨウ タンポポ・エゾノギシギシ・オオバコの 3 種が全群落で みられる。

（2）雑草群落の動態

牧草地の動態を雑草.群落の相互関係によって考察する

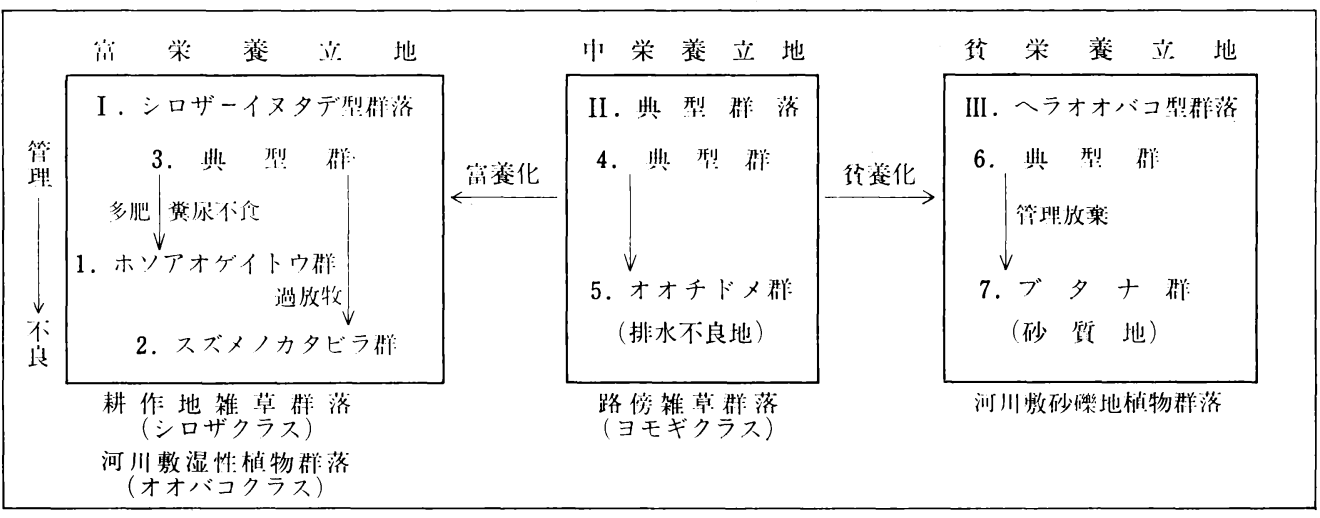

第 1 図 牧草地の雑草群落の動態（模式図） 
第 1 表 北海道牧草地雑草群落総合常在度表

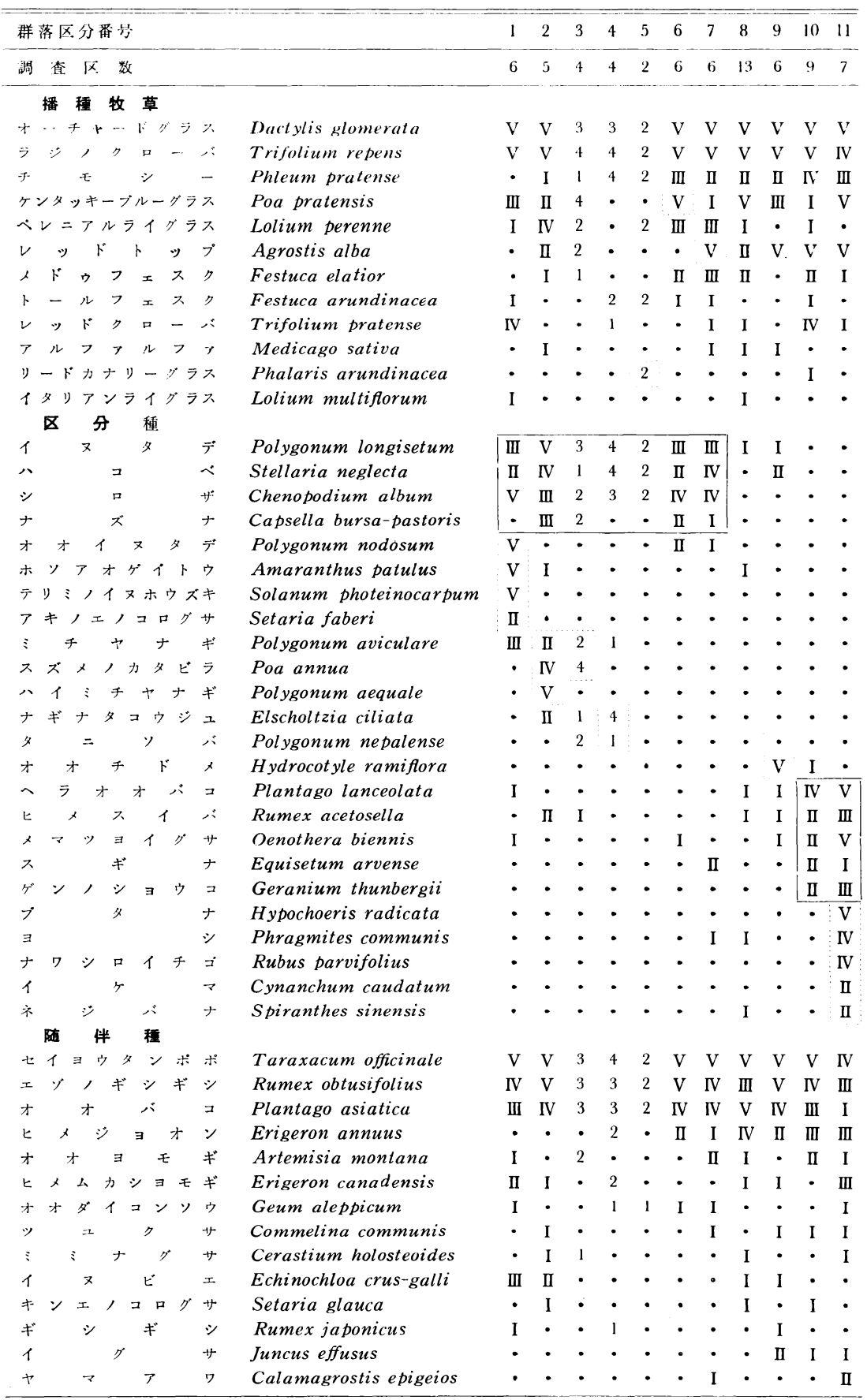

注）表中の数字は常在度を示す。算用数字は調査区数 4 以下の場合である。

場合，牧草地の基本的な立地条件，特に土壤的条件と， 人為的な管理の良・不良による牧草地の老化の程度を比 較することで, 草地雑草の動態がより明瞭となる。その
結果, 雑草による牧草地の 診断がより確実になるもの と考えられる。

卜述した北海道に掞ける 牧草地の杂隹草群落の型を, 立地条件と管理状態を両軸 にして示したのが第 1 図で ある。図の中央に示した型 は，草地として最も典型的 な生育状態を示す典型雑草 群落であり, このうち, 典 型群は中栄養立地に拈いて 適切な管理状態の下で長く 持続する。これに対し, 江 別地域にみられる泥炭土の 牧草地は, 群落区分では典 型に含まれるが，排水が極 めて悪く, オオチドメが出 現し, 牧草の生産性は低 く, 貧栄養立地のIII型に近 w。

中栄養立地において多肥 管理を続けたり，牧草地の 前歴が排水のよい沖積地や 洪積台地の耕作地である場 合, 立地条件は富栄養状態 となり,シロザ・イヌタ デ・ハコベ・ナズナなどの 一年生で好窒素性の耕地雑 草が出現し, シロザーイヌ タデ型（第 1 図左側）が成 立する。この型の雑草をも つ草地は, 管理が適切であ れば最高の生産量を示し， 安定した草地として存続し らるが，わずかな管理の失 敗によって草地は老化しや すい。第 1 図に示したよう に，放牧地において排せっ された糞尿などに基因する 不食過繁地や採草地におけ る多量施肥の場合, ホソア
オゲイトウ・オオイヌタデ・テリミノイヌホオズキなど が増加してホソアオゲイトウ群が成立する。また過放牧 の場合，スズメノカタビラ・ミチヤナギなどが増加し， 
牧草の生産力は低下する。

一方，凸状地などで砂質や碟が多い乾性で貧栄養な立 地では，ヘラオオバコ・ヒメスイバ・メマッヨイなどを 含むへラオオバコ型（第 1 図右側）が成立する。この立 地においても，多少とも恵まれた土㙵で適切な管理が行 われた場合には典型群が維持され，牧草の生産量も前述 した典型群落の草地と大差はない。しかし，牧草地の施 肥や放牧などの管理が不適切であったり，また放棄され るような場合には，土壤の物理的条件が悪化して生産性 の低い草地となる。特に酸性の砂質上壤では乾燥しやす く, 栄養分が保持しにくいため, 河川敷植物群落の種が 侵入してブタナ群が成立する。草地の生産量は, 第 1 図 で左から右方向へ，上段から下段へと低下し，ブタナ群 が最も低い。第 1 図で，I・II・III 型の群落は, 土壤立 地条件と管理方法のいかんにより，互いに移行しうるも のと考えられる。

なお,これら牧草地の雑草群落とわが国における植物 群落との関係については, 第 1 図に示したように, へラ オオバコ型と河川敷砂䃯地植物群落, ヘラオオバコ型・ 典型と路傍雑草群落, シロザーイヌタデ型と耕作地雑草 群落, スズメノカタビラ群と河川敷湿性植物群落が対応 するものと推定された。

以上のように, 牧草と共存する雑草の種の結び付きに よって種々の群落型を区分し，その動きをとらえること により牧草地の動態を明らかにした。これを 1974 年に 調査した沖繩本島安田における牧草地の動態 ${ }^{4)}$ と比較す ると, 立地条件や放牧などの管理条件によって群落が変 化することは同様であり，不食過繁地にイヌタデを主に した一年生耕地雑草群落が成立することは似ているが, 沖縄は亜熱帯に位置するため, 北海道とは群落の種組成 は非常に異なっている。

\section{（3）雑草群落と草種数}

次に,このような雑草群落の動態について, 草種数・ $\mathrm{P}$-A指数・雑草の生活型の面から考察を行いたい。

雑草群落各群における草種数の平均值を第 2 表にかか げた。各群にみられる牧草種類数は大差はないが, 雑草 種類数は典型群落・典型群が他に比較して極めて少な

第 2 表 雑草群落と草種数

\begin{tabular}{|c|c|c|c|c|c|c|c|}
\hline 草種数 & I -1 & I -2 & I -3 & II -4 & II -5 & III-6 & III-7 \\
\hline 全 種 類 数 & 12.7 & 13.7 & 11. I & 8.3 & 10.5 & 12.7 & 14. 4 \\
\hline 牧草 & 3.3 & 3.8 & 4.1 & 3.9 & 3.2 & 4.3 & 3.1 \\
\hline 雑 草 & 9.3 & 9.9 & 7.0 & 4.4 & 7.3 & 8.3 & 11. 3 \\
\hline $\mathbf{P}-\mathbf{A}$ 指 数 & -4.0 & -2.3 & 0.7 & 2.2 & 3.7 & 5.7 & 7. 3 \\
\hline
\end{tabular}

く, ブタナ群が最も多い。表中の $\mathrm{P}-\mathrm{A}$ 指数は, 昨年の 報告ら)で述べたように, 牧草地の遷移の進み方を示す指 標で, 多年生雑草の種類数から一年生並びに越年生雑草 の種類数を減じた数值であり（一)の数值の多いほど 遷移の初期であり，（十）の数值の多いほど遷移の末期 を示している。

P-A 指数で雑草群落と遷移の関係をみると, 表から 明らかなように, 群落区分番号の 1 から 7 へ順に遷移が 進んでいる。これを第 1 図の動態にあてはめてみると， 遷移は図の左欄から右欄一，富栄養立地 $\rightarrow$ 中栄養立地 $\rightarrow$ 貧栄養立地のように進行する。また管理との関係では, 管理が不良になることによって, 中栄養立地では $4 \rightarrow$ 5 , 貧栄養立地では $6 \rightarrow 7$ 一遷移は進行するが, 富栄養 立地では $3 \rightarrow 1,3 \rightarrow 2$ 人と遷移の進行は逆に戻る。こ のような群落の逆進行は, 草地の遷移というょり, 遷移 の初期段階における一時的な擋乱現象と考えられよう。

\section{（4）雑草群落と雑草の生活型}

雑草群落と雑草の生活型（休眠型・散布器官型・地下 器官型・生育型）との関係を第 2 図に示した。これは, 上述した雑草群落 $1 \sim 7$ 群について, 各群に出現した雑 草の生活型の 1 区当たり平均種類数を示したものであ る。

第一に, 休眠型では Th（一年生・越年生植物）は富 栄養立地のホソアオゲイトウ群・スズメノカタビラ群に 多く, 中栄養・貧栄養立地に少ない。 $H$ (半地中植物) は Th と反対の傾向を示し, シロザーイヌタデ型典型群 で両者は交叉する。 $\mathrm{G}$ (地中植物), $\mathrm{Ch}$ (地表植物), $\mathrm{Ph}$ (地上植物), $\mathrm{HH}$ (水生植物) は全般に少ないが, $\mathrm{Ch}$ がオオチドメ群, Gがへラオオバコ型, $\mathrm{Ph} \cdot \mathrm{HH}$ が ヘラオオバコ型ブタナ群でやや目立つ。

第二に, 散布器官型では $\mathrm{D}_{4}$ (非移動植物)の種類数は 富栄養立地のスズメノカタビラ群で多く, 典型群落典型 群で少ない。これに対し $\mathrm{D}_{1}+\mathrm{D}_{2}+\mathrm{D}_{3}$ (移動植物) の種 類数は全般に $\mathrm{D}_{4}$ より少ないが，貧栄養立地のブタナ群 で多い。移動植物のうちでは， $D_{1}$ (風・水による移動） が多く，ことに貧栄養立地のブタナ群で目立つ。

第三に, 地下器官型では $\mathrm{R}_{1 \sim 3}$ (根蕤植物) の種類数は 富栄養立地に少なく, 貧栄養立地に多い。これに対し $\mathrm{R}_{5}$ (独立根植物) は反対の傾向を示し, 富栄養立地のホソ アオゲイトウ群・スズメノカタビラ群に多く, 中栄養立 地で少ないが，貧栄養立地のブタナ群で増加している。 $\mathrm{R}_{1 \sim 3}$ と $\mathrm{R}_{5}$ の関係は，休眠型における $\mathrm{Th}$ と $\mathrm{H}$ の関係 に似ているが，これは $\mathrm{Th}$ が $\mathrm{R}_{5}$ に対応し， $\mathrm{H} ・ \mathrm{G}$ など が $\mathrm{R}_{1 \sim 3}$ に対応するためである。

第四に, 生育型では他の生活型におけるほど雑草群落 

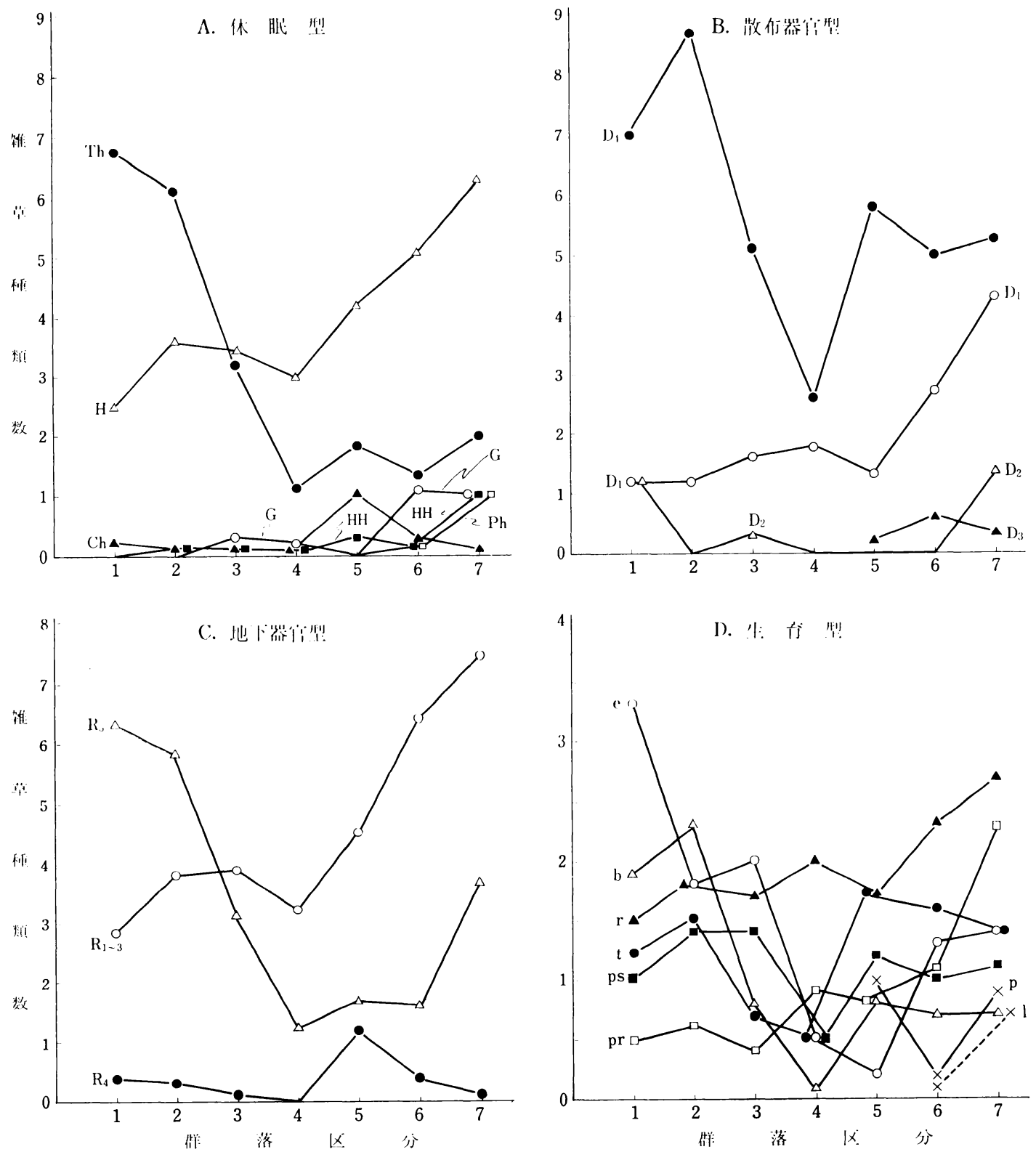

第 2 図 牧草地の群落区分と雑草の生活型別種類数

との関係は明らかでないが， e (直立型植物) がホソア オゲイトウ群で多く，また r（ロゼット型植物）は全群 落で他の型よりやや多く, pr（部分ロゼット型植物）は ブタナ群で目立つ。このような雑草群落と生活型との関

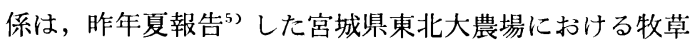
地の遷移段階と生活型との関係に類似している。

次に, 雑草群落と雑草の各種構成要素による区分 ${ }^{5)}$ と の関係を第 3 図に示した。この図の両軸は第 2 図と同じ
である。耕地雑草要素は富栄養立地に多く, 路傍雑草要 素は中栄養・貧栄養立地に多い。また路上雑草要素はス ズメノカタビラ群に多く, シバ・ススキ型要素はブタナ 群でやや多い。このような関係は，これまで述べたこと とよく一致している。

なお，これまでの調査 ${ }^{5)}$ からみて，ヘラオオバコ型群 落がさらに老化した段階に, シバ・ススキ型の草種によ って区分される群落が存在するはずであるが, 北海道の 


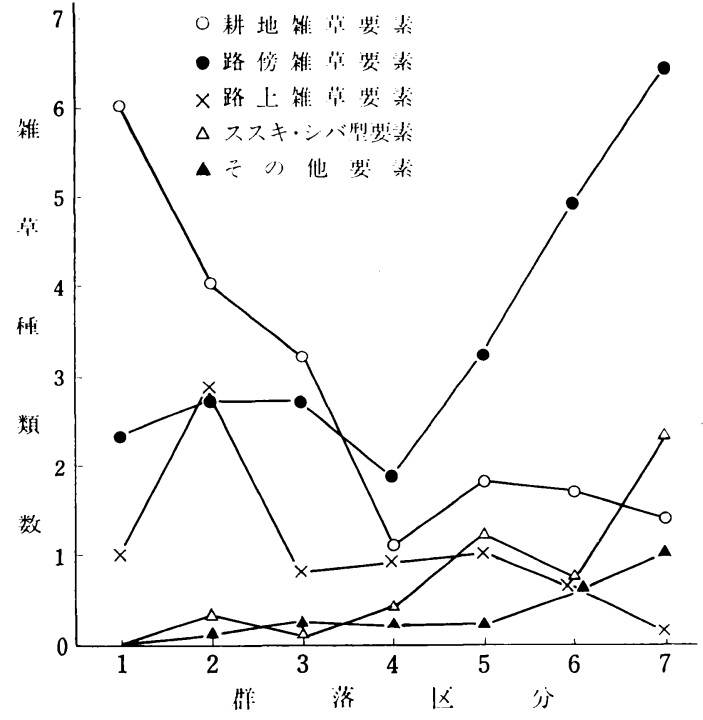

第3 3 牧草地の群落区分と各種構成要素別雑草種 類数

今回の調査では確かめることは出来なかった。

要 約

前報において, 北海道における牧草地の雑草群落の区 分を行ったが，本報ではその動態について考察した。
牧草地の雑草群落の動態は, 土䆣条件と管理条件を両 軸にしてまとめられる。I 型（シロザーイヌタデ型群落） は富栄養立地に成立するが，多肥や家畜の糞尿による不 食によってホソアオゲイトウ群に変わり, 過放牧によっ てスズメノカタビラ群に変わる。II型（典型群落）は中 栄養立地に成立するが，排水不良地ではオオチドメ群と なる。III型（ヘラオオバコ型群落）は貧栄養立地に成立 するが，砂質土塨ではブタナ群に遷移しやすい。I・ II ・III 型の群落は, 土袞条件と管理方法によって互いに 移行し得るものと考えられる。

さらに, 各種雑草群落について, $\mathrm{P}-\mathrm{A}$ 指数・生活型 の面から考察を行い，その関係を明らかにした。

\section{引用 文 献}

1）川鍋祐夫・酒井 博：畜産の研究 $28(4) \cdot(5), 487 \sim 493$. $605 \sim 610$ (1974).

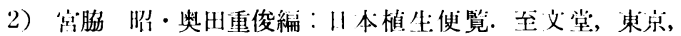
$69 \sim 88$ (1978).

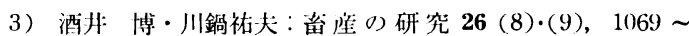
$1074 \cdot 1184 \sim 1188$ (1976).

4) 酒井 博・位藤德雄・舆田重俊・秋山价：雑卓研究 21 (3), $101 \sim 107$ (1976).

5) 酒井 博：雑草研究 23 (4), 151 159 (1978).

6）酒井 博・佐藤徳雄・奥出重俊 - 川鍋 袏夫：雑草研究 24 (3), 176 181 (1979).

(1979 年 8 月 3 日受理)

\section{Floristic Composition and the Dynamics of Weed of Sown Grassland in Japan}

II. Dynamics of Weed Communities in Sown Grasslands in Hokkaido

\section{Hiroshi SaKaI*, Tokuo Sato*, Shigetoshi OkudA** and Sukeo Kawanabe***}

* Department of Agricultre, Tohoku University, Narugo-machi, Miyagi

** Research Center of Environmental Sciences, National Yokohama University, Yokohama-shi, Kanagawa

*** Pasture Plant Division, National Grassland Research Institute, Nishinasuno-machi, Tochigi

\section{Summary}

Dynamics of weed communities of sown grasslands was analysed in the present report after having presented the classification of the weed community in a previous report.

Edaphic conditions and management of pastures such as fertilizing, mowing and grazing were most important factors in determining the dynamics of weed community. Chenopodium album-Polygonum longisetum type (Type I), which was found in the eutrophic site changed to Amaranthus patuluscommunity by heavy fertilization and as a result of the large amount of feces from grazing animals and changed to Poa annua-community as a result of overgrazing.

Typical type (Type II), observed in the mesotrophic site changed to Hydrocotyle ramifloracommunity in areas with poor drainage. Plantago lanceolata type (Type III), which was observed in 
the oligotrophic site tended to shift to Hypochoeris radicata-community in sandy soil. Thus, it appears that weed communities can shift from one to another under the influence of changes in edaphic conditions and management.

These weed communities were also discussed in relation to $\mathrm{P}-\mathrm{A}$ index and life form of composed weed species.

*** Present address : Research Center of Tropical Agriculture, Yatabe-machi, Ibaraki. 